\title{
Scrub Typhus in Uttar Pradesh, India-A Prospective Study
}

\author{
Chandra Dev Pati Tripathi', Mastan Singh ${ }^{1}{ }^{*}$, Jyotsna Agarwal ${ }^{1}$, \\ Raj Kumar Kalyan ${ }^{1}$, Chandra Kanta ${ }^{2}$ and Virendra Atam $^{3}$ \\ ${ }^{1}$ Department of Microbiology, King George's Medical University, \\ Lucknow-226003, Uttar Pradesh, India \\ ${ }^{2}$ Department of Paediatrics, King George's Medical University, \\ Lucknow-226003, Uttar Pradesh, India \\ ${ }^{3}$ Department of Internal Medicine, King George's Medical University, \\ Lucknow-226003, Uttar Pradesh, India \\ *Corresponding author
}

\begin{tabular}{|c|c|}
\hline & A B S T R A C T \\
\hline & \multirow{8}{*}{$\begin{array}{l}\text { Scrub typhus (ST) is an acute febrile illness caused by Orientia tsutsugamushi, and is } \\
\text { associated with considerable morbidity and mortality. ST has been considered as one of } \\
\text { the most emerging infections in India as shown by the increase in the number of clinically } \\
\text { diagnosed patients in various states except Uttar Pradesh. The present study was } \\
\text { undertaken to look for ST amongst patients presenting with suggestive pyrexia of } \\
\text { unknown origin (PUO) at a tertiary care centre in Uttar Pradesh. } 324 \text { serum samples from } \\
\text { clinically suspected cases collected over a period of one year, were analysed for the } \\
\text { presence of rickettsial antibodies through Weil felix test and specific IgM antibodies } \\
\text { against } O \text {. tsusugamushi by ELISA. Samples were also tested for other common causes of } \\
\text { fever prevalent in this region. Eighty two }(25.30 \%) \text { sera were found to be positive for Weil } \\
\text { feix test and } 64 \text { (19.75\%) for IgM antibodies against } O \text {. tsusugamushi. Positivity was } \\
\text { significantly higher among males }(P<0.05) \text { between } 0 \text { and } 15 \text { yrs of age. The common } \\
\text { symptoms noted were fever, myalgias, hepatosplenomegaly, and gastrointestinal } \\
\text { complaints, followed by breathlessness, rash and jaundice. Fever was the most common } \\
\text { manifestation (100\%) and the pathognomonic feature; eschar was present only in } 2(3.1 \%) \\
\text { patients. Our results showed that scrub typhus should be considered in the differential } \\
\text { diagnosis of acute febrile illness and empirical treatment with doxycycline may be given in } \\
\text { cases with strong suspicion of scrub typhus. }\end{array}$} \\
\hline & \\
\hline & \\
\hline & \\
\hline $\begin{array}{l}\text { Scrub typhus, } \\
\text { Weil Felix test. }\end{array}$ & \\
\hline Article Info & \\
\hline $\begin{array}{l}\text { Accepted: } \\
12 \text { March } 2017 \\
\text { Available Online: } \\
10 \text { April } 2017\end{array}$ & \\
\hline & \\
\hline
\end{tabular}

\section{Introduction}

Scrub typhus is an acute infectious disease caused by Orientia tsutsugamushi, a Gramnegative intracellular coccobacillus. The larvae of trombiculid mites are the implicated vector and reservoir of the bacteria and can efficiently transmit it to their offspring transovarially (Mahajan, 2005; Nakayama et $a l ., 2010)$. It presents as either as nonspecific febrile illness with legitimate symptoms such as fever, rash, myalgias, headache, lymphadenopathy, hepatospleno-megaly, rash and an eschar or with organ dysfunctions involving organs such as kidney (acute renal failure; ARF), liver (hepatitis), lungs (acute respiratory distress syndrome, ARDS), central nervous system (meningitis), or with 
circulatory collapse with haemorrhagic fevers (Mahajan, 2005) Scrub typhus is one of the differential diagnoses (in addition to leptospirosis, malaria or dengue fever) in patients with haemorrhagic fever especially if associated with jaundice and/or renal failure (Kothari et al., 2006). Scrub typhus is endemic in the geographical region known as "tsutsugamushi triangle" (Chogle, 2010). In India, epidemics of scrub typhus have been reported from north, east and south India (Mathai et al., 2001; Varghese et al., 2006; Kamarasu et al., 2007; Vivekanandan et al., 2010; Mahajan et al., 2008; Somashekar et al., 2006; Sharma et al., 2005). Although the disease is endemic in our country, it is grossly under diagnosed owing to the non-specific clinical presentation, lack of access to the specific diagnostic facilities in most areas, and low index of suspicion by the clinicians (Batra, 2007). There has been an increased incidence of ictero-haemorrhagic fevers presenting to our institution in the recent past. After ruling out complicated malaria, and dengue fever, many of these cases remained undiagnosed. Scrub typhus has been reported in neighbouring states, hence the present study was undertaken to know the burden of scrub typhus amongst clinically suspected patients attending a tertiary care centre in Uttar Pradesh using Weil- Felix (WF) and Scrub typhus IgM ELISA test.

\section{Materials and Methods}

This was a prospective study (hospital based surveillance) and the study population included individuals of all age groups, attended the outpatient and inpatient departments of a tertiary care centre in the state of Uttar Pradesh with a diagnosis of pyrexia of unknown origin (PUO) or experiencing a febrile illness clinically consistent with rickettsiosis infection during January 2015 to December 2015.
A questionnaire designed to note down the demographic details (so that follow up of patient is easy for collection of paired sera) and clinical findings of the suspected patient. The protocol and study with patients was approved by the Ethics committee of the King George's Medical University, Lucknow (approval no. 7215/Ethics/R. Cell-15) and written informed consent was obtained from patients before enrollment to this study. All the human subjects underwent clinical examination by the clinician for rickettsial and other possible infections.

$3 \mathrm{ml}$ each of whole blood samples collected in plane vial and serum was separated and aliquoted. All samples were stored in duplicate at $-80^{\circ} \mathrm{C}$ for future analysis. When available, convalescent paired sera were also tested to enhance the diagnosis sensitivity.

Each sample was tested for Scrub typhus specific tests viz. ELISA for O. tsutsugamushi IgM antibodies and Weil felix test for all the 3 antigens OXK, OX2 and OX19 using commercial kits (InBios International, Inc., USA for ELISA and Tulip Diagnostics, Goa for Weil Felix Test) following manufacturer's protocol.

Antigens Proteus vulgaris OX2, P. vulgaris OX19 and P. mirabilis OXK were obtained commercially from Tulip Diagnostics, Goa, India. Weil Felix test was done using manufacturer's protocol. In brief, the smooth, killed recolored antigen suspensions were blended with the patient's serum. Antibodies produced because of rickettsial disease if display in the patient serum was respond with the recolored antigen suspension to create an agglutination response. No agglutination demonstrates the nonattendance of rickettsial antibodies.

Samples were tested using Orientia tsutsugamushi ELISA IgM kit (InBios 
International, Inc., USA) as per manufacturer's protocol. In brief, patient sera and control sera (positive and negative) were used at a dilution of 1:100 using sample dilution buffer and kept for 30 minutes at $37^{\circ}$ C. After washing, $100 \mu \mathrm{l}$ of an Enzyme-HRP was added for 30 minutes at $37^{\circ} \mathrm{C}$. After washing, $150 \mu \mathrm{l}$ of EnWash was added to all wells for 5 minutes at room temperature (20$25^{\circ} \mathrm{C}$ ). Finally, after washing the substrate solution containing tetramethylbezidine was added for 10 minutes at room temperature and the plate was read at $450 \mathrm{~nm}$ within 1 hour of stopping. Endemic titre of ELISA was being done by calculating the cut-off value using the average of OD + 3SD of normal human serum and/or human sera with unrelated infections i.e. cut-off $=$ average $\mathrm{OD}+3 \mathrm{SD}$.

Weil Felix and Orientia tsusugamushi IgM ELISA tests were translated by the producer's rules. A titre of over 1:80 was considered as positive for OXK, OX2 and OX19 antigens for Weil Felix Test and optical density (OD) above 0.6 considered positive for $\operatorname{IgM}$ antibody. The patients having of $\operatorname{IgM}$ antibodies against $O$. tsutsugamushi in their serum samples as well as OXK antigen titre above 1:80 were diagnosed as having scrub typhus.

Differential diagnosis of malaria (antigen detection, Optimal, Bio-Rad Laboratories India Pvt. Ltd., Gurgaon, Haryana, India), dengue (NS1 antigen, Microlisa, J. Mitra \& Co. Pvt. Ltd., New Delhi, India), typhoid (Typhidot, AB Diagnopath Manufacturing Pvt. Ltd, New Delhi, India; Widal; in-house) and hepatitis (Merilisa HBsAg, Meril Diagnostics Pvt. Ltd., Vapi, Gujarat, India) etc. was performed using commercial kits following manufacturer's protocol to see the associated co-infections, if any.

Patients were subjected to a series of investigations including urine analysis, complete blood count, platelet count, Renal
Function Tests (RFT), Liver Function Tests (LFT), smear for malarial parasite, rapid antigen test for malaria, typhoid and dengue haemorrhagic fever and blood culture as per clinicians' judgement. Patients were also subjected to further investigations such as bleeding and clotting time, prothrombin time / International normalized ratio (INR), activated partial thromboplastin time, fibrin degradation products, abdominal ultrasonography, chest X-ray, wherever deemed necessary to confirm the diagnosis.

The data was statistically analysed on SPSS 16 software by using Chi-square $\left(\mathrm{X}^{2}\right)$ test. In statistical analysis by Chi-square test, the probability value ( $p$ value) of less than 0.05 was considered significant.

\section{Results and Discussion}

A total of 324 consecutive patients with PUO were included in the study and $64(19.75 \%)$ were positive either by Scrub typhus IgM ELISA or Weil felix test both. Weil Felix picked up 82 cases as positive and of these only 64 were positive in ELISA. There was $100 \%$ correlation between ELISA and Weil Felix test. Of the 324 samples, the samples positive by ELISA were also positive by Weil felix test. There was overwhelming predominance of scrub typhus amongst males $(P<0.05)$ (Table 1$)$. The age of the patients ranged from 2 to 80 years. Among males with FUO, positivity for ST IgM antibody was highest in $0-15$ years $(30.8 \%)$ followed by 31 45 years of age group (22.2\%). In females highest positivity was also seen in $0-15$ years $(25 \%)$. On statistical analysis, the difference in positivity for ST in different age group amongst males was significant $(\mathrm{P}<0.05)$ but not so for females (Table 1). Most of the patients were from rural areas of various districts of the state of Uttar Pradesh (Fig. 1). Regarding occupation, most of our patients were farmers and self- employed. Majority of the cases were seen between the months of 
August to December (Fig. 2). Fever was the most common manifestation (100\%). Common symptoms along with fever at the time of presentations included headache, myalgia, nausea and vomiting, breathlessness, gastrointestinal complaints such as abdominal pain and loose motions, rash and jaundice. The commonest signs seen were hepatomegaly $(81.3 \%)$ and splenomegaly $(68.8 \%)$. Clinical features in the two groups are described in table 2. Nearly half of patients $(50 \%)$ had clinical features suggestive of capillary leak syndrome in form of anasarca, icterus, pallor, pedal oedema, hypotension and low serum albumin. The pathognomonic features such as eschar was not commonly seen in the present study; being present only in two patients $(3.1 \%)$. Among the laboratory investigations, leukocytosis $(75.0 \%)$, raised transaminases (81\%) [mean SGOT (aspartate transaminase)/ SGPT (alanine transaminase) were 254/135IU/1] and alkaline phosphatase ( 58\%) patients (mean $186.4 \mathrm{IU} / \mathrm{l}$ ) and low serum albumin (53\%) were main findings (Table 3). In the present study, all patients were empirically treated with injection ceftriaxone and amikacin. Once serology reports were available on day two, patients were treated with doxycycline empirically in the dosage of $100 \mathrm{mg}$ twice a day for 10 days on the clinical suspicion of scrub typhus. There was rapid improvement in patient's condition and most of them became afebrile within 24-48 $\mathrm{h}$ and were discharged within next 7-9 days; except for four patients who presented late to hospital with multiple organs dysfunction and did not survive (mortality rate $6.25 \%$ ).

The outbreaks of scrub typhus have been reported from various parts of the country in the recent past with serological evidence of widespread occurence of scrub typhus in the neighbouring States (Mathai et al., 2001; Varghese et al., 2006; Kamarasu et al., 2007; Vivekanandan et al., 2010; Mahajan et al.,
2008; Somashekar et al., 2006; Sharma et al., 2005). Thus, there was a strong possibility of presence of scrub typhus in Uttar Pradesh also but no information was available yet. In the present study we for the first time are reporting a prevalence of nearly $20 \%$ of scrub typhus in clinically suspected patients reporting at a tertiary care centre in Uttar Pradesh. The occurrence of scrub typhus varied with age, gender and occupation. Our results showed that the incidence of infection was higher particularly in the male pediatric age group followed by female pediatric age group, possibly due to increased exposure as a result of a propensity for outdoor activities. Bithu et al., (2014) also reported pediatric male preponderance in their study. Most of the patients were from rural background. A large number of our patients were from Lakhimpur-Kheri, Sitapur, Raebareli, Bahraich, Hardoi, Sultanpur, Shravasti and Gonda districts. These districts are usually associated with specific habitats such as abandoned plantations, gardens or rice fields, overgrown forest clearings, shrubby fringes of fields and forests, river banks and grassy fields. These ecological patches may attract the natural host of mite vectors are called "mite islands". Similar ecological niches were also observed in other places of India where scrub typhus has been reported (Mittal et al., 2012; Wei et al., 2014). Most of the cases were reported during the months of August to December. This coincides well with the active period of mites; during or at the end of rainy season. Similar period of disease occurrence is reported earlier also. Additionally, in the immediate post monsoon period (September to early months of the next year), there is growth of secondary scrub vegetation, which is the habitat for trombiculid mites (mite islands) (Narvencar et al., 2012).

The disease presents as an acute febrile illness with non-specific signs and symptoms. In the present study, the commonest presentation seen was that of fever with myalgias $(73 \%)$ or 
with rash (48\%). Another important finding was predominance of gastrointestinal signs and symptoms such as nausea and vomiting, abdominal pain, and loose motions. This finding assumes importance, as there is limited available information on the relationship between scrub typhus and gastrointestinal dysfunction (Aung et al., 2004). Since clinical presentation of fever with rash/ myalgia occurs in many other febrile illnesses like leptospirosis or dengue fever, presence of gastrointestinal complaints could be used as a differentiating feature for suspecting scrub typhus. Establishing the aetiological diagnosis is difficult during the acute stage of illness and the clinical features may be confused with atypical measles, dengue, malaria, sepsis, meningococcaemia, leptospirosis and vasculitis syndromes. These were ruled out clinically and by investigations in our patients. None tested positive for any other infections. A necrotic eschar at the inoculating site of the mite is pathognomonic of scrub typhus however it is rarely seen in south East Asia and Indian subcontinent. In our study, eschar was seen in only two patients. Though lymphadenopathy is common in scrub typhus (Mahajan et al., 2006) however, in the present study, nearly half of the patients showed this sign.
Similar to other studies (Varghese et al., 2006; Vivekanandan et al., 2010), most patients had elevation of serum transaminases, even without any other evidence of multiorgan dysfunction. Other laboratory findings noted were leukocytosis, hepatomegaly, splenomegaly, thrombocytopenia, and low serum albumin. While low serum albumin and leucocytosis are thought to be associated with severe scrub typhus (Kim et al., 2010; Lee et al., 2009). The central pathophysiological derangements, liver function, renal function and thrombocytopenia in ST is because of wide spread vasculitis and perivasculitis of these organs. This is due to multiplication of the organism in the endothelial cells lining the small blood vessels and consumption of platelets in the process of intravascular microthrombosis (Koh et al., 2010). The mainstay of diagnosis in scrub typhus is serology (Kim et al., 2008). The gold standard serological tests are immunoflorescence antibody test or indirect immunoperoxidase assay but are out of reach in our country owing to high costs and lack of expertise. The cheapest test currently available and used extensively in our country is WeilFelix test which is highly specific, but lacks sensitivity (Batra, 2007; Aung et al., 2004). The test shows false negative results in the early stage of disease as the agglutinating antibodies can be detected only in the second week of illness.

Table.1 Age and sex distribution of pyrexia of unknown origin cases

\begin{tabular}{|c|c|c|c|c|c|c|}
\hline \multirow{2}{*}{$\begin{array}{l}\text { Age group } \\
\text { (years) }\end{array}$} & \multicolumn{3}{|l|}{ Male } & \multicolumn{3}{|c|}{ Female } \\
\hline & Total & $\begin{array}{l}\text { Positive } \\
(\%)\end{array}$ & $\begin{array}{l}\text { Negative } \\
(\%)\end{array}$ & Total & $\begin{array}{l}\text { Positive } \\
(\%)\end{array}$ & $\begin{array}{l}\text { Negative } \\
(\%)\end{array}$ \\
\hline $0-15$ & 78 & $24(30.8)$ & $54(69.2)$ & 56 & $14(25)$ & $42(75)$ \\
\hline $16-30$ & 49 & $3(6.1)$ & 46 (93.9) & 35 & $6(17.1)$ & $29(82.9)$ \\
\hline $31-45$ & 36 & $8(22.2)$ & $28(77.8)$ & 23 & $3(13)$ & $20(86.9)$ \\
\hline $46-60$ & 27 & $4(14.8)$ & $23(85.2)$ & 10 & $1(10)$ & $9(90)$ \\
\hline$>60$ & 8 & $1(12.5)$ & $7(87.5)$ & 2 & $0(0)$ & $2(100)$ \\
\hline \multirow{2}{*}{ Total } & 198 & $40(20.2)$ & $158(79.8)$ & 126 & $24(19)$ & $102(80.9)$ \\
\hline & & \multicolumn{2}{|c|}{$\begin{array}{l}\text { Chi-square }\left(\boldsymbol{X}^{2}\right)=12.30 \\
\text { Degree of freedom } \\
(\text { dof })=4 \\
\boldsymbol{P} \text { value }=<0.05\end{array}$} & & \multicolumn{2}{|c|}{$\begin{array}{l}\text { Chi-square }\left(\boldsymbol{X}^{2}\right)=2.91 \\
\text { Degree of freedom } \\
(\mathbf{d o f})=4 \\
\boldsymbol{P} \text { value }=>0.05\end{array}$} \\
\hline
\end{tabular}


Table. 2 Clinical features of the scrub typhus patients (values in parentheses are percentages)

\begin{tabular}{|c|c|c|c|c|c|c|c|}
\hline \multicolumn{4}{|c|}{ Scrub typhus patients } & \multicolumn{4}{|c|}{ Non Scrub typhus patients } \\
\hline Features & $\begin{array}{c}\begin{array}{c}\text { No. of } \\
\text { patients } \\
n=64 \\
(\%)\end{array} \\
\text { (\%) }\end{array}$ & Clinical signs & $\begin{array}{l}\begin{array}{l}\text { No. of } \\
\text { patients }\end{array} \\
\text { n=64 } \\
(\%)\end{array}$ & Features & $\begin{array}{c}\begin{array}{c}\text { No. of } \\
\text { patients } \\
\text { n= 260 } \\
(\%)\end{array} \\
\text { (\%) }\end{array}$ & Clinical signs & $\begin{array}{l}\text { No. of } \\
\text { patients } \\
n=260 \\
(\%)\end{array}$ \\
\hline $\begin{array}{l}\text { Fever } \\
<7 \text { days }\end{array}$ & $21(32.8)$ & Pallor & $30(46.9)$ & $\begin{array}{l}\text { Fever } \\
<7 \text { days }\end{array}$ & $52(20)$ & Pallor & $154(59.2)$ \\
\hline $\begin{array}{l}\text { Fever } \\
7-13 \text { days }\end{array}$ & $37(57.8)$ & Cyanosis & $21(32.8)$ & $\begin{array}{l}\text { Fever } \\
7-13 \text { days }\end{array}$ & $74(28.4)$ & Cyanosis & $123(47.3)$ \\
\hline $\begin{array}{l}\text { Fever } \\
14-29 \text { days }\end{array}$ & $4(6.3)$ & Icterus & $33(51.6)$ & $\begin{array}{l}\text { Fever } \\
14-29 \text { days }\end{array}$ & 48 (18.4) & Icterus & $118(45.3)$ \\
\hline $\begin{array}{l}\text { Fever } \\
>30 \text { days }\end{array}$ & $2(3.1)$ & $\begin{array}{l}\text { Lymphadenop } \\
\text { athy }\end{array}$ & $26(40.6)$ & $\begin{array}{l}\text { Fever } \\
>30 \text { days }\end{array}$ & $86(33)$ & $\begin{array}{l}\text { Lymphadenop } \\
\text { athy }\end{array}$ & $138(53)$ \\
\hline Headache & 49 (76.6) & Pedal oedema & $24(37.5)$ & Headache & 168 (64.6) & Pedal oedema & $106(40.7)$ \\
\hline $\begin{array}{l}\text { Abdominal } \\
\text { pain }\end{array}$ & $35(54.7)$ & Eschar & $2(3.1)$ & $\begin{array}{l}\text { Abdominal } \\
\text { pain }\end{array}$ & $123(47.3)$ & Eschar & $0(0.00)$ \\
\hline $\begin{array}{l}\text { Loose } \\
\text { motions }\end{array}$ & $19(29.7)$ & $\begin{array}{l}\text { Hypotension/ } \\
\text { shock }\end{array}$ & $27(42.2)$ & \begin{tabular}{|l|}
$\begin{array}{l}\text { Loose } \\
\text { motions }\end{array}$ \\
\end{tabular} & $86(33)$ & $\begin{array}{l}\text { Hypotension/s } \\
\text { hock }\end{array}$ & $102(39.2)$ \\
\hline Myalgias & $47(73.4)$ & \begin{tabular}{|l|} 
Altered \\
sensorium
\end{tabular} & $36(56.3)$ & Myalgias & $177(68)$ & $\begin{array}{l}\text { Altered } \\
\text { sensorium }\end{array}$ & $147(56.5)$ \\
\hline Rash & $31(48.4)$ & Hepatomegaly & $52(81.3)$ & Rash & $157(60.3)$ & Hepatomegaly & $168(64.6)$ \\
\hline $\begin{array}{l}\text { Nausea/ } \\
\text { vomiting }\end{array}$ & $52(81.3)$ & Splenomegaly & $44(68.8)$ & $\begin{array}{l}\text { Nausea/vom } \\
\text { iting }\end{array}$ & $138(53)$ & Splenomegaly & $138(53)$ \\
\hline Jaundice & $27(42.2)$ & $\begin{array}{l}\begin{array}{l}\text { Features of } \\
\text { capillary leak }\end{array} \\
\end{array}$ & $24(37.5)$ & Jaundice & $119(45.7)$ & $\begin{array}{l}\text { Features of } \\
\text { capillary leak }\end{array}$ & $99(38)$ \\
\hline $\begin{array}{l}\text { Breathlessne } \\
\text { ss }\end{array}$ & $30(46.9)$ & & & $\begin{array}{l}\text { Breathlessn } \\
\text { ess }\end{array}$ & $132(50.7)$ & & \\
\hline Anasarca & $23(35.9)$ & & & Anasarca & 144 (55.3) & & \\
\hline $\begin{array}{l}\text { Decreased } \\
\text { urine output }\end{array}$ & $18(28.1)$ & & & $\begin{array}{l}\text { Decreased } \\
\text { urine output }\end{array}$ & $122(46.9)$ & & \\
\hline $\begin{array}{l}\text { Coryza and } \\
\text { Cough }\end{array}$ & $29(45.3)$ & & & $\begin{array}{l}\text { Coryza and } \\
\text { Cough }\end{array}$ & $148(56.9)$ & & \\
\hline $\begin{array}{l}\text { Bloody nasal } \\
\text { discharge }\end{array}$ & $11(17.2)$ & & & \begin{tabular}{|l} 
Bloody \\
nasal \\
discharge
\end{tabular} & $94(36.1)$ & & \\
\hline
\end{tabular}


Table.3 Laboratory investigations of Scrub typhus cases (values in parentheses are percentages)

\begin{tabular}{|l|l|}
\hline Investigations & $\begin{array}{l}\text { No. of patients } \\
\mathbf{n}=\mathbf{6 4}(\%)\end{array}$ \\
\hline Low haemoglobin $(<9.0 \mathrm{gm} \%)$ & $39(60.9)$ \\
\hline Leucocytosis $(>12,000 / \mu \mathrm{l})$ & $48(75)$ \\
\hline Thrombocytopenia $\left(<0.15 \times 10^{6} / \mu \mathrm{l}\right)$ & $24(37.5)$ \\
\hline Raised bilirubin $(>1.2 \mathrm{mg} \%)$ & $39(60.9)$ \\
\hline Raised SGPT/SGOT $(>40 \mathrm{IU} / \mathrm{l})$ & $52(81.3)$ \\
\hline Raised alkaline $\mathrm{PO}_{4}(>130 \mathrm{IU} / \mathrm{l})$ & $37(57.8)$ \\
\hline Raised serum creatinine $(>1.4 \mathrm{mg} \%)$ & $28(43.8)$ \\
\hline Raised serum urea $(>45 \mathrm{mg} / \mathrm{dl})$ & $49(76.6)$ \\
\hline Low serum albumin $(<3.0 \mathrm{gm} \%)$ & $34(53.1)$ \\
\hline Low blood pressure $(<100 / 60 \mathrm{~mm} \mathrm{Hg})$ & $26(40.6)$ \\
\hline High respiratory rate $(>40 / \mathrm{minute})$ & $31(48.4)$ \\
\hline High pulse rate $(>100 / \mathrm{minute})$ & $27(42.2)$ \\
\hline
\end{tabular}

Fig.1 Distribution of Scrub typhus in Uttar Pradesh (This map was taken from http://www.mapsofindia.com/maps/uttarpradesh/tehsil/). Asterisks indicate the occurrence of scrub typhus patients

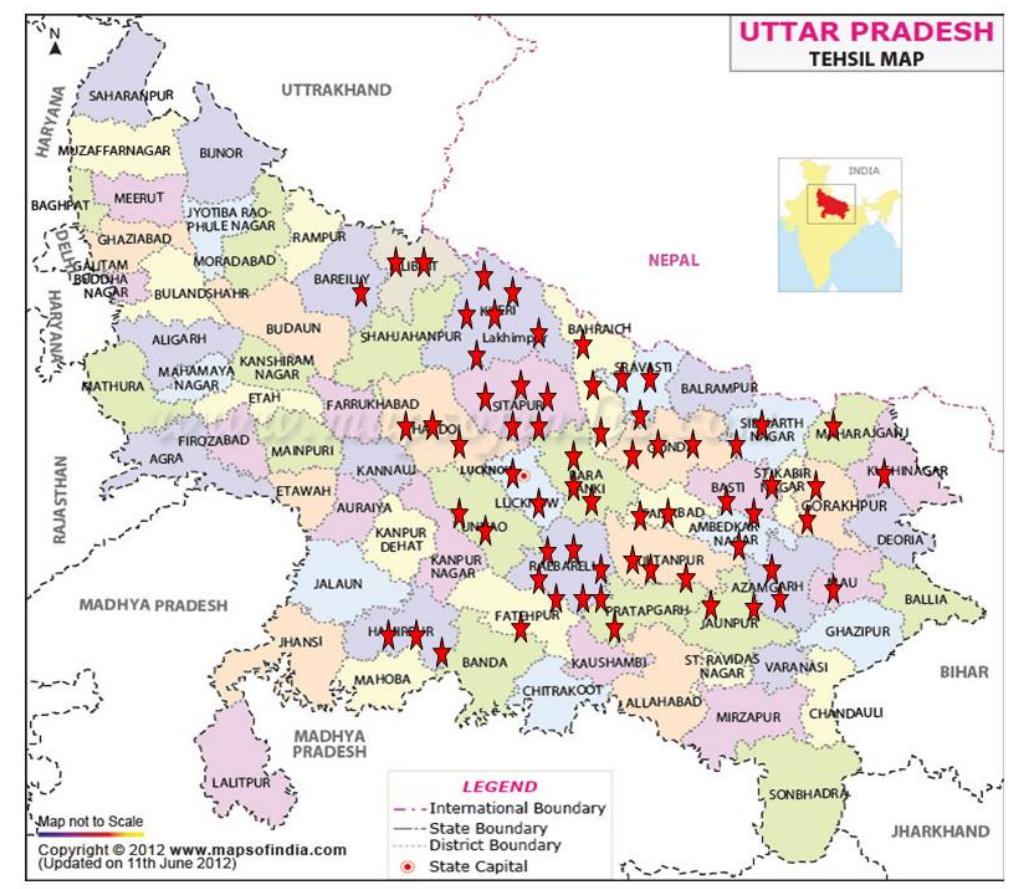


Fig.2 Distribution of total and scrub typhus cases around the year

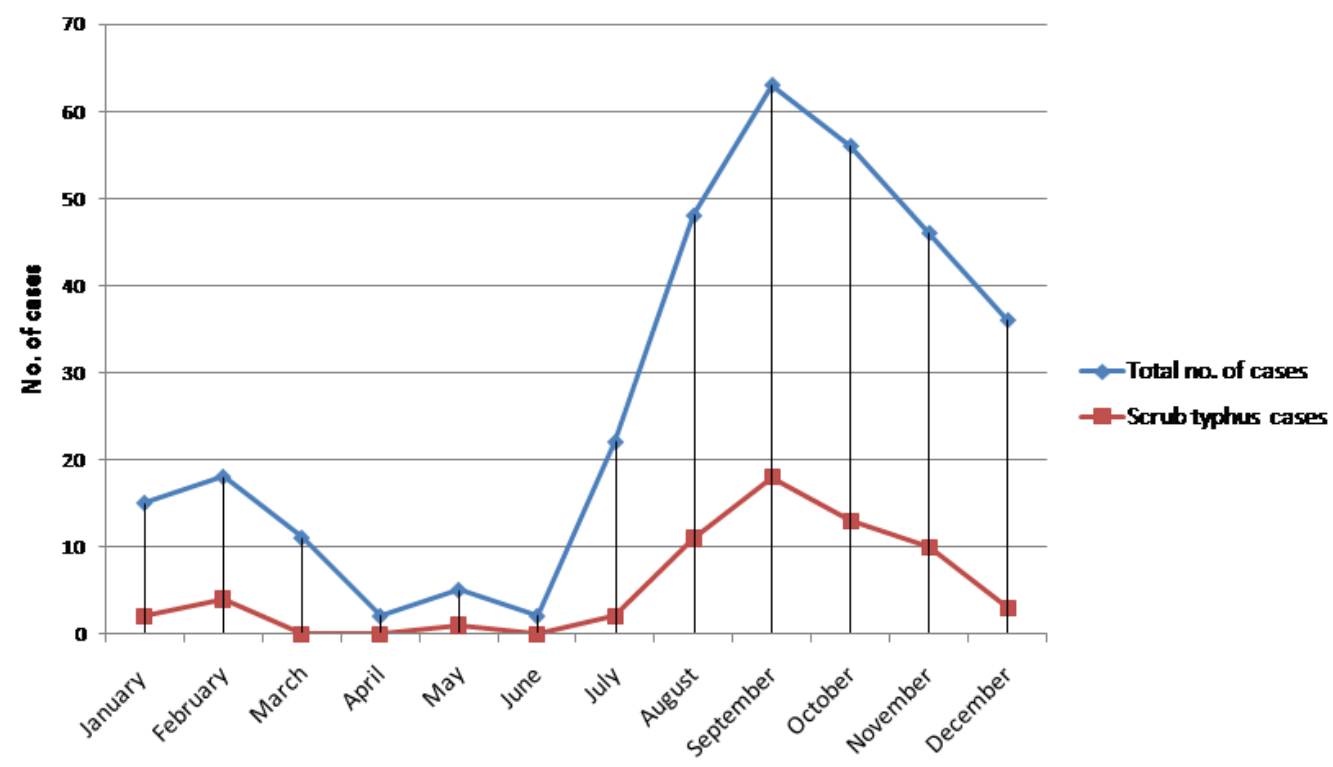

The IgM ELISA has good sensitivity and specificity, it is easy to perform, gives swift results and is suitable for testing large number of specimens; hence it may be considered as good replacement for Weil-Felix test and IFA test for diagnosis of scrub typhus. In the present study, we used both Weil felix for rickettsial antibodies and ELISA testing for specific IgM antibodies against $O$. tsutsugamushi for diagnosis. ELISA test has shown good sensitivity and specificity (Lee et al., 2009) and has been adequately validated.

Complications in scrub typhus develop after first week of illness and are directly related to the blood load of $O$. tsutsugamushi (Seong et al., 2001; Sonthayanon et al., 2009). In the present study, the most common organ dysfunction was hepatomegaly, splenomegaly followed by gastrointestinal disfunction and multi organ failure. Definitive diagnosis usually requires heightened clinical suspicion and examination of paired serum samples for serological evidence (Walker et al., 2012). Here we have reported most of the confirmed cases of scrub typhus where clinical suspicion followed by examination of paired serum samples for serological evidence, confirmed the diagnosis and prompt treatment led to recovery in most of the patients. The present study is about patients presenting at our centre which is a tertiary referral centre where patients are referred from peripheral primary care or district level for complications. This referral bias has led to high complication rate in this study. Two patients had acute encephalitis syndrome which has not been reported earlier. In our study, four patients succumbed to disease (mortality rate $6.25 \%$ ). This is relatively lower as compared to other studies. All patients who died had presented with multi organ dysfunction; of these, two had not received tetracyclines or macrolides. In other two patients, doxycycline was initiated late (second week of illness). The results of the present study will have major contribution towards providing information on prevalence of rickettsial infections in the community so that effective control measures can be implemented. This will also give a unique opportunity to validate clinical signs and symptoms of rickettsial infections and 
agreement between clinically suspected and laboratory proven cases. Further this will evaluate utility of serodiagnosis in our set up and for early and reliable detection of 'difficult-to-diagnose' and 'easy-to-treat' rickettsioses pathogens.

In conclusion, our study showed that scrub typhus should be considered in the differential diagnosis of acute febrile illness associated with gastrointestinal symptoms, rash, myalgias, including those with organ dysfunctions such as hepatorenal syndrome, coagulopathy or ARDS. Though eschar is pathognomonic of the disease, it may not be commonly seen, and its absence does not rule out scrub typhus. Delay in treatment may lead to complications and higher mortality. As patients respond to doxycycline or macrolides, empirical treatment with these antibiotics may be given in cases where there is a strong suspicion of scrub typhus.

\section{Acknowledgements}

We are thankful to all the clinicians who have sent samples during the study period.

\section{References}

Aung, T., Supanaranond, W., Phumiratanaprapin, W., Phonrat, B., Chinprasatsak, S., Ratanajaratroj, N. 2004. Gastrointestinal manifestations of septic patients with scrub typhus in Maharat Nakhon Ratchasima Hospital. Southeast Asian J. Trop. Med. Public Health, 35(4): 845-851.

Batra, H.V. 2007. Spotted fevers and typhus fever in Tamil Nadu. Indian J. Med. Res., 26(2): 101-103.

Bithu, R., Kanodia, V., Maheshwari, R.K. 2014. Possibility of scrub typhus in fever of unknown origin (FUO) cases: An experience from Rajasthan. Indian J. Med. Microbiol., 32(4): 387-390.

Chogle, A.R. 2010. Diagnosis and treatment of scrub typhus the Indian scenario. $J$. Assoc. Physicians India, 58: 11-12.

Ittyachen, A.M. 2009. Emerging infections in Kerala: a case of scrub typhus. Natl. Med. J. India, 22(6): 333-334.

Kamarasu, K., Malathi, M., Rajagopal, V., Subramani, K., Jagadeeshramasamy, D., Mathai, E. 2007. Serological evidence for wide distribution of spotted fevers and typhus fever in Tamil Nadu. Indian J. Med. Res., 126(2): 128-130.

Kim, D.M., Kang, D.W., Kim, J.O., Chung, J.H., Kim, H.L., Park, C.Y. et al. 2008. Acute renal failure due to acute tubular necrosis caused by direct invasion of Orientia tsutsugamushi. J. Clin. Microbiol., $46 \quad$ (4): 1548-1550. doi:10.1128/jcm.01040-07

Kim, D.M., Kim, S.W., Choi, S.H., Yun, N.R. Clinical and laboratory findings associated with severe scrub typhus. BMC Infect. Dis., 10: 108 doi:10.1186/1471-2334-10-108

Koh, G.C., Maude, R.J., Paris, D.H., Newton, P.N., Blacksell, S.D. 2010. Diagnosis of scrub typhus. Am. J. Trop. Med. Hyg., $82 \quad$ (3): $\quad 368-370$ doi:10.4269/ajtmh.2010.09-0233

Kothari, V.M., Karnad, D.R., Bichile, L.S. 2006. Tropical infections in the ICU. $J$. Assoc. Physicians India, 54: 291-298.

Lee, C.S., Hwang, J.H., Lee, H.B., Kwon, K.S. 2009. Risk factors leading to fatal outcome in scrub typhus patients. Am. $J$. Trop. Med. Hyg., 81(3): 484-488.

Mahajan, S.K. 2005. Scrub typhus. J. Assoc. Physicians India, 53:954-958

Mahajan, S.K., Kashyap, R., Kanga, A., Sharma, V., Prasher, B.S., Pal, L.S. 2006. Relevance of Weil-Felix test in diagnosis of scrub typhus in India. $J$. Assoc. Physicians India, 4: 619-621.

Mahajan, S.K., Rolain, J.M., Sankhyan, N., Kaushal, R.K., Raoult, D. 2008. Pediatric scrub typhus in Indian Himalayas. Indian J. Pediatr., 75(9): 
947-949. doi:10.1007/s12098-0080198-Z

Mathai, E., Lloyd, G., Cherian, T., Abraham, O.C., Cherian, A.M. 2001. Serological evidence for the continued presence of human rickettsioses in southern India. Ann. Trop. Med. Parasitol., 95(4): 395398. doi:10.1080/00034980120065804

Mittal, V., Gupta, N., Bhattacharya, D., Kumar, K., Ichhpujani, R.L., Singh, S. et al. 2012. Serological evidence of rickettsial infections in Delhi. Indian $J$. Med. Res., (135): 538-41.

Nakayama, K., Kurokawa, K., Fukuhara, M., Urakami, H., Yamamoto, S., Yamazaki, K., et al. 2010. Genome comparison and phylogenetic analysis of Orientia tsutsugamushi strains, DNA Res., 17: 281-91.

Narvencar, K.P., Rodrigues, S., Nevrekar, R.P., Dias, L., Dias, A., Vaz, M., et al. Scrub typhus in patients reporting with acute febrile illness at a tertiary health care institution in Goa. Indian J. Med. Res., 136(6): 1020-1024.

Seong, S.Y., Choi, M.S., Kim, I.S. 2001. Orientia tsutsugamushi infection: Overview and immune responses. Microbes Infect., 3: 11-21.

Sharma, A., Mahajan, S., Gupta, M.L., Kanga, A., Sharma, V. 2005. Investigation of an outbreak of scrub typhus in the himalayan region of India. Jpn. J. Infect. Dis., 58(4): 208-210.

Somashekar, H.R., Moses, P.D., Pavithran, S., Mathew, L.G., Agarwal, I., Rolain, J.M. et al. Magnitude and features of scrub typhus and spotted fever in children in India. J. Trop. Pediatr., 2(3): 228-229. doi:10.1093/tropej/fmi096

Sonthayanon, P., Chierakul, W., Wuthiekanun, V., Phimda, K., Pukrittayakamee, S., Day, N.P. et al. 2009. Association of high Orientia tsutsugamushi DNA loads with disease of greater severity in adults with scrub typhus. J. Clin. Microbiol., 47(2): 430434. doi:10.1128/jcm.01927-08.

Varghese, G.M., Abraham, O.C., Mathai, D., Thomas, K., Aaron, R., Kavitha, M.L. et al. 2006. Scrub typhus among hospitalised patients with febrile illness in South India: magnitude and clinical predictors. J. Infect., 52(1): 56-60. doi:10.1016/j.jinf.2005.02.001

Vivekanandan, M., Mani, A., Priya, Y.S., Singh, A.P., Jayakumar, S., Purty, S. 2010. Outbreak of scrub typhus in Pondicherry. J. Assoc. Physicians India, 58: 24-28.

Walker, D.H., Dumler, J.S., Marrie, T. 2012. Rickettsial diseases. In: Longo DL, Fauci AS, Kasper DL, Hauser SL, Jameson JL, Loscalzo J, editors. Harrison's principles of internal medicine, 18th ed. New York: McGraw-Hill; 2012. p. 1407-17.

Wei, Y., Huang, Y., Luo, L., Xiao, X., Liu, L., Yang, Z. 2014. Rapid Increase of scrub typhus: An epidemiology and spatial-temporal cluster analysis in Guangzhou City, Southern China, 20062012. PLoS One, 9: e101976.

\section{How to cite this article:}

Chandra Dev Pati Tripathi, Mastan Singh, Jyotsna Agarwal, Raj Kumar Kalyan, Chandra Kanta, Virendra Atam. 2017. Scrub Typhus in Uttar Pradesh, India- A Prospective Study. Int.J.Curr.Microbiol.App.Sci. 6(4): 977-986. doi: https://doi.org/10.20546/ijcmas.2017.604.123 